\title{
Large City Architecture: the mereological mode of the quantified city
}

\section{Daniel Köhler}

To cite this article: Daniel Köhler (2017) Large City Architecture: the mereological mode of the quantified city, International Journal of Parallel, Emergent and Distributed Systems, 32:sup1, S163S172, DOI: $10.1080 / 17445760.2017 .1390109$

To link to this article: https://doi.org/10.1080/17445760.2017.1390109
(c) 2018 The Author(s). Published by Informa UK Limited, trading as Taylor \& Francis Group

曲 Published online: 15 Feb 2018.

Submit your article to this journal $\widetilde{ }$

Џ Article views: 857

Q View related articles $\sqsubset$

View Crossmark data $\asymp$ 


\section{Large City Architecture: the mereological mode of the quantified city}

\section{Daniel Köhler}

Faculty of Architecture, Institute of Urban Design, University of Innsbruck, Innsbruck, Austria

\begin{abstract}
With the reading of Ludwig Hilberseimer's Grosz-stadt-Architektur simply as "Large City Architecture," the description of the city changes from a notion of political intervention to one of quantitative examination. Thereby and when the urban is defined as "being situated in a city," urbanism can be extended with schemata of the design of the city itself: the resonance of its parts, its mereological compositions. In such a reading, architectural knowledge overlaps with digital thought. A mereological examination of the city, based on quantitative methods allows an interface to technical, digital representations of places and buildings. This is different to common incorporations of the digital in urban design, which mainly focuses on continuous, morphological differentiations. BIM-models can be described as the nesting and incorporation of multiple representations of objects and algorithms. However, today's models focus only on the internal organization of one object, not its assembly. Through a digital reading of part-conditions in historic city models, this paper opens the possibility to enrich the evolving, and so far technocratic representations of places and buildings with the architectural knowledge of the city and its history.
\end{abstract}

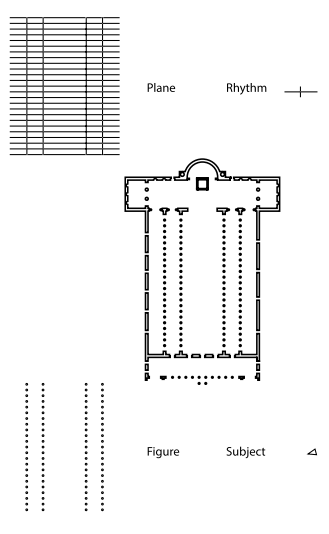

Modern Composition as described in Architecture History

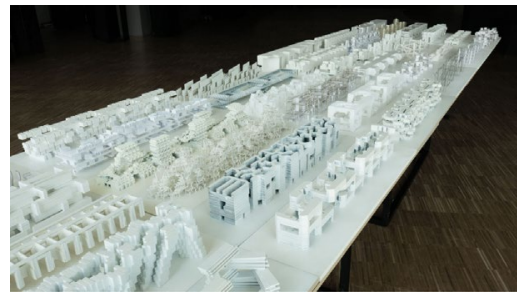

is parallel to Digital Thought.

This opens new possibilities for the city and its architecture.

\section{ARTICLE HISTORY}

Received 27 November 2016

Accepted 21 May 2017

\section{KEYWORDS}

Mereology; parthood conditions; urbanism; digital architecture; Hilberseimer; BIM 


\section{From metropolitan architecture to Large City Architecture}

At the beginning of the twentieth century, many urbanists were under the spell of the Groszstadt, and so was the art-critique, teacher and urbanist Karl Ludwig Hilberseimer. The German term Groszstadt is mostly translated with Metropolis [1]. However, the Greek word Metropolis literally means 'MotherCity', referring to a city as political centre, i.e. as a capital: the mother of cities. Similar, research on the metropolis and its architecture focusses on the representational meaning of the city and its politics. On the following pages, I want to draw an argument for a much more direct translation of the Groszstadt simply as Large-City. As I will show, early research into the Groszstadt as phenomenon - especially apparent in the schemata of Ludwig Hilberseimer - refers to the quantity of the city, its size and the architectural problem of an order of masses. Therefore, I will begin to translate Groszstadt with Large City, to amplify the quantified aspect of an architectural problem. Consequently, freed from the semantic tension of form and content, such notion offers an entry point for digital thought in the realm of city architecture as a design method.

Ludwig Hilberseimer named his first manuscript written in 1914: Die Architektur der Groszstadt [2]. The unpublished paper holds the same title as the renowned book by Karl Scheffler about the city of Berlin, which appeared only one year earlier [3]. It is not only the title of the text that is a reference to the writings of Schefflers; Hilberseimer also starts with the same principles as Karl Scheffler. The Large City is declared in both writings to be the central topic of architecture. The new economic conditions of industrialization determine the character of the Large City. Thus, the Large City differs from the historical city, which evolved from a need for protection and thus a local binding of capital. Up to this point, both works are congruent.

However, further on Scheffler bypasses economic circulation to changes in family constellations. In this, Scheffler puts the family on the same level as the apartment as the smallest cell of urban morphology. The biology of humans is transcribed verbatim on to the urban organism. If the challenge for urban design is to adapt the urban morphology to economic conditions, Scheffler's coupling of family

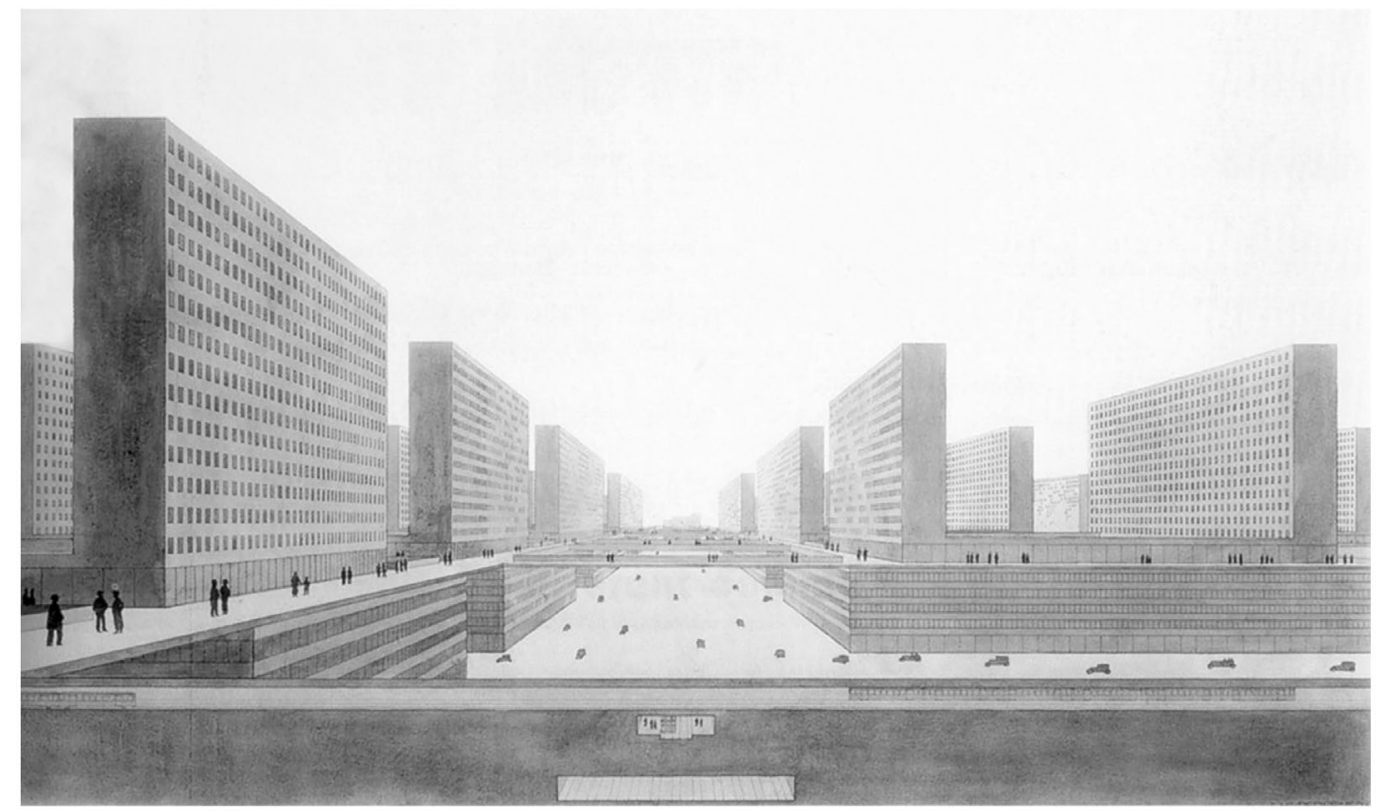

Figure 1. Ludwig Hilberseimer, schema of the Vertical City, perspective North-South-Street, analytical representations by author, original: series 10/2a, Box. FF 1.4, Ludwig Karl Hilberseimer Papers, Ryerson \& Burnham Archive, Art Institute Chicago. 
with architecture leads to the urban-political conclusion to group small families to the production sites. According to this pairing, it is only logical that the 'living cell' of a nuclear family reflects the recurring characteristics of the industrial worker. Drawn together into the large units corresponding to a factory, Scheffler's metropolis consists of uniform and free-standing blocks. Consequently, the façades of city blocks should express the uniformity of labour life circumstances and are treated in the unitary rhythm. For Scheffler, architecture is directly linked to the social fabric of the city, its content. The form of the city is an expression of its economy. Therefore, for Karl Scheffler, architecture becomes infrastructure, as the transmitting of politics towards a physical reality. Contrary to Scheffler, Ludwig Hilberseimer is not interested in an adaptation of the city to the social situation. He recognizes that the mode of the industrial Large City has generated new architectural typologies [4]. Hilberseimer makes it clear that his point is to examine how the elements of the city are related to each other and to the city in general. The new city should be built based on its elements, so instead of a mere juxtaposition of elements, on a series of the needs of the elements. But what are the problems and needs of a city? How is 'city' transferred into an architectural problem? What defines architectural elements and their relationship to each other? These are the core issues that Hilberseimer is trying to answer in his treatise: Large City Architecture (Figure 1).

\section{The resolution of the Large City scheme}

His treatise is built around the representation of his city schema of the Vertical-City [5]. The name, literally tall-house-city, represents the vertical organization principle of the city rather than the metric height. The proposal is organized into four city elements, each consisting of twelve by ten city blocks. The length of a city block corresponds to the distance between two underground stations, an enormous $600 \mathrm{~m}$. The demonstrated city blocks of the Vertical City have twenty storeys. The lower five floors of a city-block contain the business city, the top fifteen the residential city. In the perspectives, the façades of the residential city are distinguished from the commercial city: the commercial city is divided by horizontal window strips and the residential city shown with a punctuated façade. If one locates the point of view of the perspective North-South- Street in the plan schema, one can observe that the perspective was constructed extremely abbreviated. When seen, one expects phenomenological an ordinary slab with an average length of $70 \mathrm{~m}$. However, compared with the plan scheme, the length of a city block is $600 \mathrm{~m}$. The extreme perspective shrinks the perceived distances. When constructing the residential slab with the shown number of punctuations, it is clear that in relation to the plan the hole of a façade-punctuation has a real length of approximately $15 \mathrm{~m}$. The distance between the punctuations is about $15 \mathrm{~m}$. The punctuations in the façade cannot represent. By himself, Hilberseimer explicitly emphasizes in the textual description that the representations are without any design intention. The renderings are schemata, not absolute architectural representations.

Zooming into his plan schema, Hilberseimer shows an exemplary apartment layout, consisting of six different residential units, which vary in size and room allocation by number of beds, between one and six. Additionally, each apartment has an entrance hall, a kitchen, a bathroom, a living area and a loggia. If one now constructs a block in the scale of the rendering with apartment units represented by loggias as punctuations of the city block's façade, the appearance of the construction is congruent to Hilberseimer's representation of the façade. As it turns out, the punctuation in the perspective façade stands for a loggia and thus a residential unit. As schematic representation, the façades in the perspectives embody the structural logic of the underlying apartment cells. The perspective represents the structure of several apartment elements of living in a large form, the city block.

What then would be an explicit architectural formulation of such a schema? Considering the presented apartment floor plans, one cannot obtain a homogeneous partitioned façade. In each of the proposed six examples, the position of the loggia is different. If one reads the schema of the rendering as a description of the connection between apartments and the city, the perforation of the façade first of all means an overlap of the city block with a specific amount of housing units. Hilberseimer establishes a specific intersection of flat and city block. Hilberseimer does not make absolute specifications 


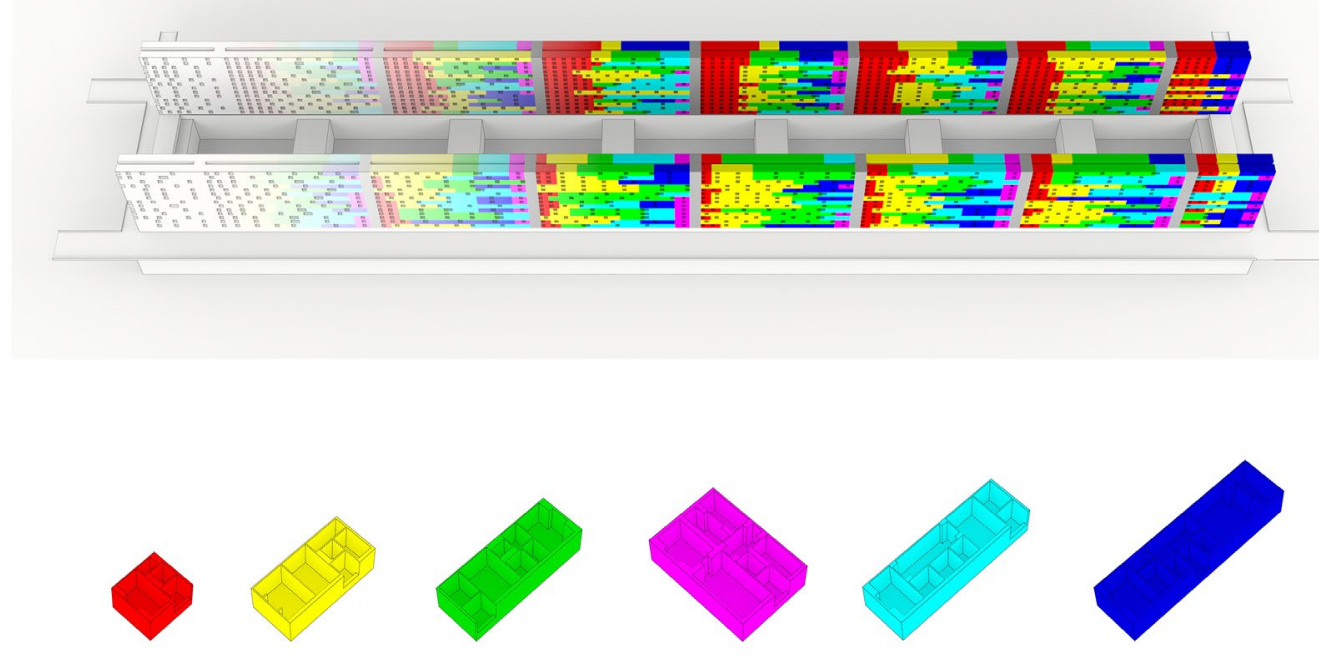

Figure 2. Ludwig Hilberseimer, schema of the Vertical City, top: architectural representation of one city-block with loggias, bottom: six exemplary apartment units.

of the location of the apartments in relation to each other; the location of the apartments along the corridor is variable. The modularity of the rooms and the apartments are multiples of each other. Only the location of the staircase and corridor is determined (Figure 2).

As a result, the recombination of apartment cells within the span of two staircases is possible. In this way, a compositional space is created that allows variation by arrangement and combination. Assuming a steady, equal distance between two staircases in the scheme of the Vertical City and using only the six developed example types of apartments, the number of permutations taking into account the absolute size of the units, is 182.68 . Following the schematic representation, a city block has 7 staircases, therefore multiplying 7 sections by 14 residential floors by 2 slabs per block by 10 by 12 blocks per city element by 4 City units, so the presented city for 4 million residents consists of 94.080 sections between two staircases. The schematic structure of the basic plan-typologies thus already allows twice as many variations than it has explicit situations. In Large City Architecture, one does not find variation and difference in the figure, but in its figuration.

\section{From contrast to rhythm}

Obviously, the depicted perspectives of the Vertical City are clearly insufficient to express any of those complexities. The sheer mass of replicated loggias, as representative of a part- interval, become in the renderings a plane without background. The interval between the parts eludes of an observable description. The assembly as fabric is perceived as a single block. The parts of the composition are absorbed to what Hilberseimer terms as 'Groszform' (En. large form).

The homogeneity of such large forms is an essential characteristic of modernist aesthetics. Therefore, modernism is often defined by the criticism of the effect of its surfaces and their smoothness. Accordingly, the modern is often framed as an epoch following the ornament [6] and preceding the decorated shed [7]. In such a view, it is assumed that the texture of the surface directly affects the observer. Therefore, the design of an object and its criticism focusses on the direct link between the appearance of an object's surface and its effect on an observer. 
In particular, Hilberseimer's perspective demonstrates the linear nature of such criticism of architecture. Similar to a mathematical equation, observation is opposed to architecture or in the plural: society is opposed to the city. Alterations on the one side leads to change on the other side. In Hilberseimer's case, on the one hand the façades of the Vertical City described as mass ornament were argued as the result of a redundant, Fordist society [8]. On the other hand, the large form of the city was compared to diagrams of social science, rendering this form of city equivalent to impoverished forms of society [9]. In their conclusions, these forms of criticisms demand more resolution and porosity (Figure 3).

However, as shown, Hilberseimer's large form contains more possible variation than is articulable, but it remains invisible. So in order to break through the surface of large form, additional compositional elements have to be located outside the equation of observer and object.

A source for an initial search on the nature of the large form can be found in his writings as an artcritic, where he builds on the work and methods of the art historian Alois Riegl. Frequently quoted by Hilberseimer [10], one finds in Riegl's work the beginning of formal analysis in art history. As art historian, Riegl rejected any substantive discussion as metaphysical speculation. As a work of art was not a cultural product in Riegl's opinion, his methods developed a possible description of the work of art with the artwork and the elements of which it consists. Investigating the relation between figures, figurations and the role of rhythm, his writings seems a good transition between art, architecture and the investigations on the nature of classes and sets in modern logic (Figure 4).

Riegl differentiated between classic and modern composition [11]. Both the classical and the modern are distinct from each other through the role of rhythm. Classical rhythm is a rhythm of contrast. Also named triangular composition, referring to the triangle of perspective view, the distance between observer and artwork defines a semiological dimension. Classical rhythm describes meaning as an associative effect between the observer and a figure [12]. In consequence, classic composition is an act of framing. Varying the frame of perspective view - for Riegl ranging from close-view to far-view - the ratio between object and subject constitutes meaning [11]. Projected back in three dimensions, the role of architecture is to construct the frame by limiting a subject's surroundings in a certain ratio, indicating meaning. In its simplest form, this is via the placement of walls as a limit of the range of view. The articulation of the wall's surface creates the illusion of more or less distance and so pushes the frame towards a close- or more far-view. Classical rhythm is therefore interested in the variation of perceptible value.

Modern composition is different. Termed by Riegl as 'quadratic composition', modern rhythm describes a mode of arrangement [11]. Riegl recognized that certain forms of artwork cannot be framed through direct perception. These artworks consist of several individual forms already contained by three-dimensional space. Surrounded by a particular depth of open space, these forms are still considered coherently. A rhythm of intervals between the figures pointing in every direction (quadratic) renders them into one plane as long as the depth between the figures is not too deep. Of notable interest for the modern rhythm is not the contrast or variation between the figures, but the levelling between bright, forward-springing individual forms and the dark shadows of open space. Not frameable by the contour of a figure, the rhythm is dependent on an interval of light and shadow. As a result of this, modern composition is interested in the collective character of the apparent individual forms. In contrast to the classical interest in contrasting figures, here rhythm is oriented 'towards simplification and massing' [11] (Figure 5).

Described in this way, modernism is a particular expression of composition, which can be distinguished from other forms of compositional expression, like the classical. Through the quantitative assessment of their parts and wholes, modernism is at first a specific condition released from its historical epoch or mode of production. Its main characteristic, according to Riegl, is the independency of rhythm, levelling figures into a single mass-composition. Separated from the link between observer and object, rhythm adds a third element to the composition of a whole. At the time of Riegl this is best described by Edmund Husserl under the term linkage-whole [13]. Husserl defines the linkage-whole through the types of relation of parts to each other. It is compositeness - Riegl's rhythm -, which describes a whole. A link is an entity in which parts are joined together with the help of a concept. 


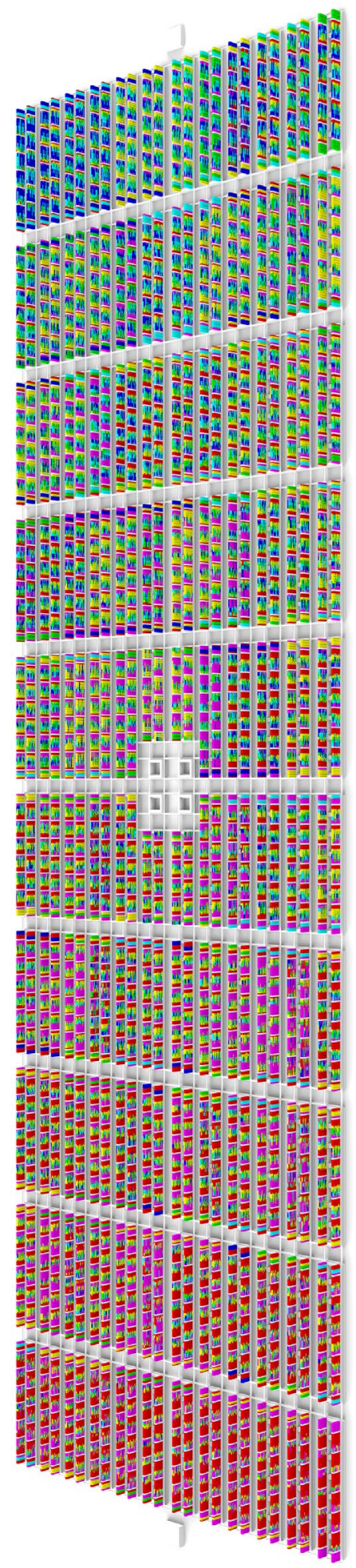

Figure 3. Ludwig Hilberseimer, schema of the Vertical City, axonometric of one city element, colour coding of the six exemplary units. 

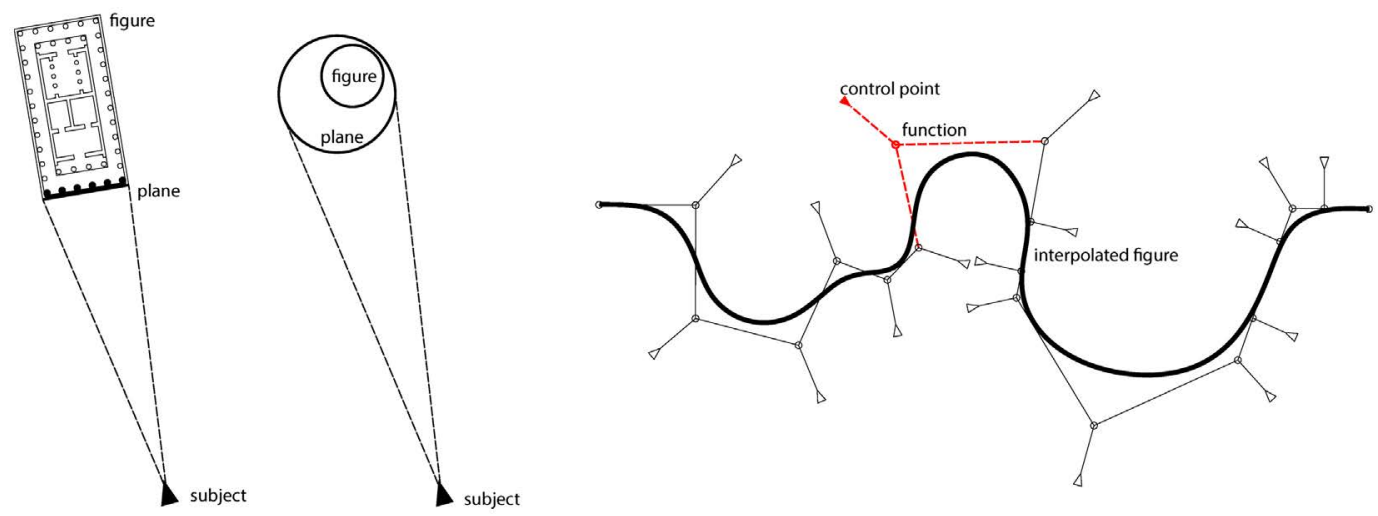

Figure 4. Classical composition as a triangular constellation between subject, perceivable plane and architectural figure, abstracts the architectural figure to a perceptible plane. This is comparable to the abstraction of parts to particles via interpolation towards a control point.

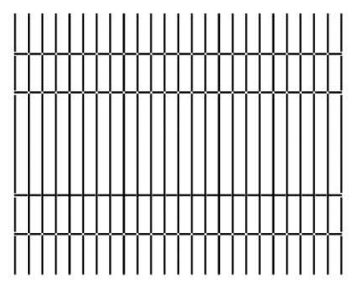

Plane

Rhythm

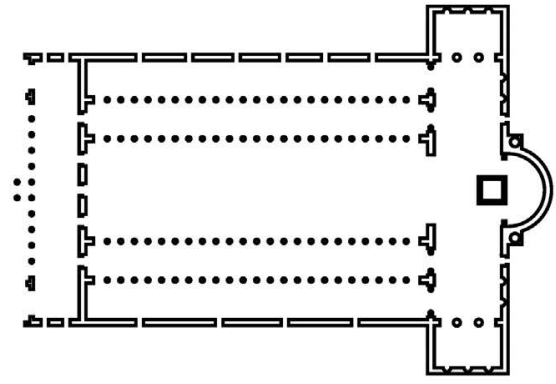

Subject
Figure

$\Delta$

Figure 5. Modern Composition describes architecture as a quadruple between subject, plane, rhythm and architectural figure, according to Alois Riegl in Late Roman Art Industry.

A figure is such a linkage. The determination of the whole is here external; a conception of the whole is not part of the whole itself. Husserl uses the term grounding as a description of the relationship and linkage of the parts, a unified grounding with which any part or content, directly or indirectly linked, describes a whole. A whole can thereby be reduced to the concomitance of its parts. Husserl does not presuppose the concept of the whole. In essence, the concept of the whole is dispensable here [14]. During the mid-1950s, these concepts and formal investigations on the conception of figurations were transferred into mathematical logic by Nicolas Rescher and Paul Oppenheim and thus found its way into the early attempts of system theory and computer science [15]. In the tradition of Husserl's writings, Rescher and Oppenheim assume that a real whole can never be fully described. Analogous to Husserl, the whole and thus the concept of figure in this way describes a system of dependency. The description of a whole by means of a relation is equal to the functional and integrated whole. This leads to the following characteristics of a whole: the whole must have a structure. For a structured whole, three things are necessary: its parts, a domain of positions, which occupy the parts and an assignment that assigns to the part to a specific position. In Riegl's terminology: the figures, the plane and the rhythm. 


\section{Largeness: the mode of digital logistics}

Typically, for a three-body-problem, any singular element can be expressed by infinite constellations of the other two elements. In other words: the number of wholes is infinite with a finite number of parts. Vice versa, a whole can be drawn by an infinite number of different parts. Precisely, the dependency of the finite number of parts creates diversity. Therefore, modern composition is not concerned with contours, contrast and variation, but with simplification. At this point, composition overlaps with the Digital. Literally meaning the act of pointing with a finger (Latin: digitus), the digital is the ability to represent values as discrete [16]. Before computation: the art of counting and calculus, the digital deals with the problem of how one can represent a number from a continuous, analogous spectrum. In the first place, the digital makes things countable. Therefore, the making of a unit from large quantities is a major issue. Riegl would have described the nature of such process as mass composition. Modern massing is based on what machines do best: repeating. If a pattern, the modern rhythm of an interval, is considered certain, proofed by its repeatability - a pure quantitative assessment and its Largeness [17] - the assembly is hidden by explicit closure. Furthermore, it becomes a resource as one thing for more complex types of arrangements. In this way, modern rhythm, interested in simplification, enables the possibility of the nesting and grouping of heterogeneous elements. Known in computer programming as encapsulation, this method is scale independent and infinitely stackable. Consciously, this process is two-sided: what is closed can be opened again and what is a unit can be rendered as an assembly of assemblages. The moment of simplification, the modern rhythm can be understood as interface between what is considered as discrete and what is an assemblage. Such an interface is articulated by the resonance of its parts: by what I call Largeness. What is singular is not a placeholder, icon, index or symbol, but the effect of compressed quantities. In digital models, one navigates through complexities not horizontally by reference or analogy, but vertically through stacks of large quantities. Therefore, digital logistics are described in the words of Benjamin Bratton:'as chains of interfaces: spatial discontinuous assemblage lines' [18]. Assemblage lines are not imaginable as simple wires, but in themselves, they are braided, even matted bundles consisting of packs of discrete parts, where parts of a pack might belong to different lines and chains [19]. Unfortunately, digital architecture has never been modern, building on modes of classical composition. Chaining, the composition of assemblage lines and the design of these vertical interfaces is today an urgent, but unnoticed design problem (Figure 6).

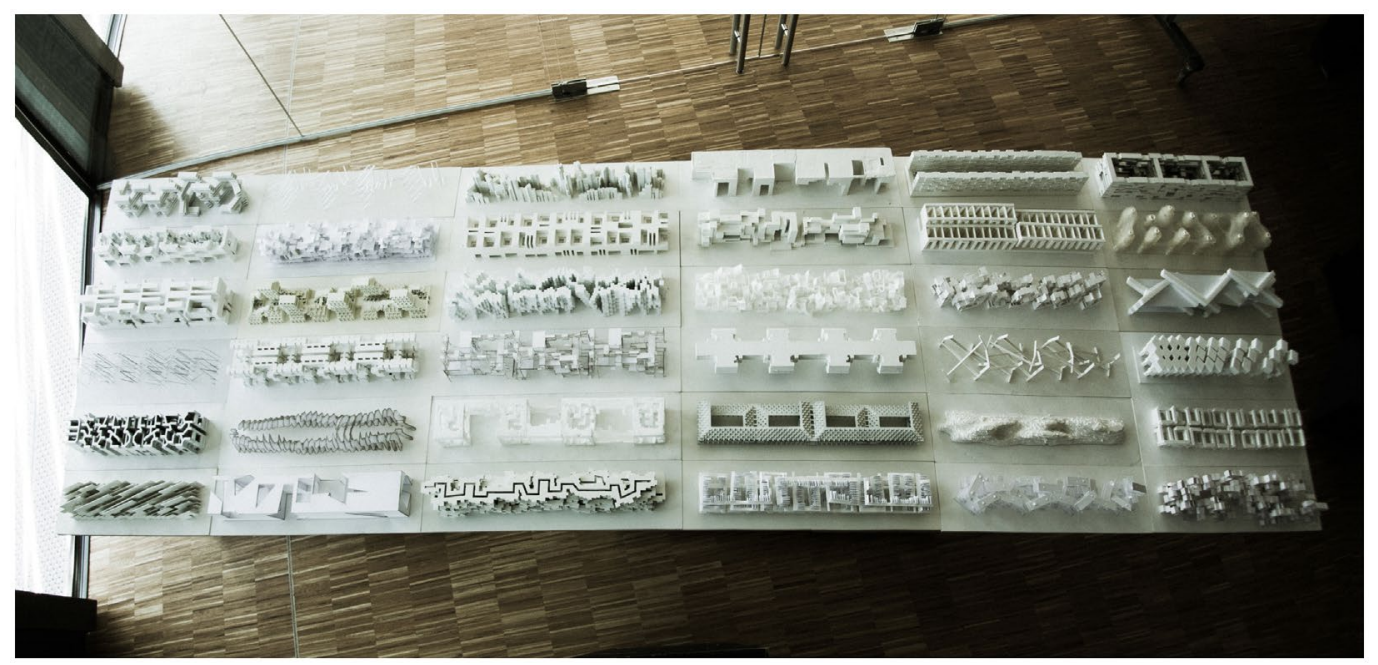

Figure 6. The Mereological City, top view. Each model renders an existing part condition between the city and its architecture, student models, urban design exercise at the Institute of Urban Design, University of Innsbruck, led by Daniel Köhler. 


\section{The city as a grain of architecture}

The Vertical-City schema was Hilberseimer's response to an emerging economic, political state of the city: the industrialization and at a larger picture: capitalism. Hilberseimer began his response by describing the city of capital's final state as'vast ocean of buildings' [20]: the endless city, the stage of complete urbanization. This is where we are today.

Now, one century later, as predicted by modernists like Hilberseimer the building industry increasingly makes use of prefabricated, discrete elements and assembles those via interfaces, called 'Building Information Modelling'. In short, BIM-objects are nothing more than interfaces to digital representations of places and buildings. These representations consist of geometrical elements associated with information und behaviors. A BIM-object receives information to modify certain geometrical aspects according to inherent rules and it gathers information describing certain qualities of the geometrical part [21]: BIM-objects are discrete, encapsulating geometry, behaviors and observations. Concealing operability, such models amplify the parts of the building. Furthermore, through the uncertainty of their consistence, they become independent from the building design as such. Withdrawn from the architect's influence, in practice the design of a building is a process of sorting, comparing and combining building parts. The representation of the building itself consists of other BIM-objects, defined at different levels of aggregation. Finally, BIM-objects can be described as the nesting and incorporation of multiple representations of objects and algorithms. Called levels of detail, these nestings are defined today by the building industry according to the design phases of building construction: from geometric shape, to generalized and specific description, to complete fabrication information and to constructed form [22]. In their current state, BIM models only progress modes of construction. Here architectural research is in demand to develop a comparable mode of existence.

As predicted by Hilberseimer with his perspectives, only horizontal diversity of figures leads to flatness and uniformity at the scale of the current Large City. In Large City Architecture, the focus shifts from an interest in the quality of its surfaces and contours, towards possible modes of property, access and habitability. Departing from modernism in a positive reading, the promise arise that we can edit, hack and exacerbate that of which it is made: its interfaces, its rhythm [23].

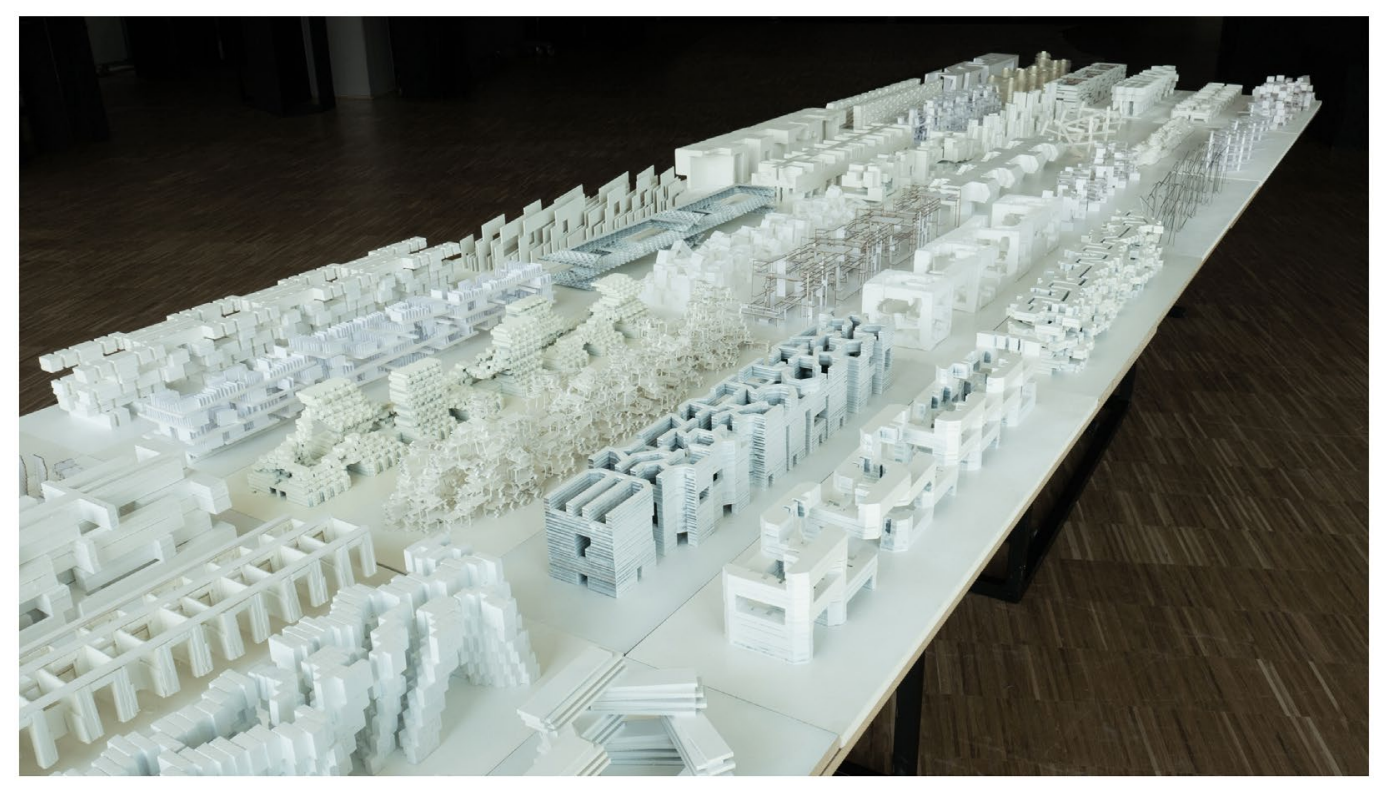

Figure 7. The Mereological City, perspective view. 
At the beginning of modernism as mode of production, Alberti famously drew the city as a large house and the house as a small city. Counted by digital logistics, such a comparison becomes rather interesting in the contemporary city. If digital objects are discrete, concealed assemblies, then the city cannot be compared and placed next to a house, like in classical composition. In digital representation, the city has to be encapsulated in architecture. As plot, as compartment wall, as shaft, as window area: with digital logistics, the city is described, measured, regulated and molded into explicit parts of architecture. The city is articulated as a physical part of a building for the building facing the city. So one might begin to ask, what precisely is considered as a 'city' in an architectural part? Further, what part is mandatory, shareable, removable, separable or exchangeable? Moreover, most importantly: What grain of resolution might your part of the city have? (Figure 7).

\section{Disclosure statement}

No potential conflict of interest was reported by the author.

\section{References}

[1] Anderson R, editor. Metropolisarchitecture and selected essays. Vol. 2. New York (NY): Columbia University Press; 2013.

[2] Hilberseimer L. Die Architektur der Groszstadt. The Art Institute of Chicago: [publisher unknown]; 1914.

[3] Scheffler K. Die Architektur der Groszstadt. Berlin: Bruno Gassierer Verlag; 1913.

[4] Hilberseimer L. Groszstadt Architektur. Stuttgart: Julius Hoffmann; 1927. p. 12.

[5] Hilberseimer L. Groszstadtbauten. Hannover: Apossverlag; 1925. p. 14.

[6] Spuybroek L. The sympathy of things: Ruskin and the ecology of design. Rotterdam: V2_Publishing; NAi Publishing; 2011. p. 75-143.

[7] Lynn G, editor. Folds, bodies \& blobs: collected essays. Bruxelles: La Lettre volée; 1998.

[8] Tafuri M. Architecture and utopia: design and capitalist development. Cambridge (MA): MIT press; $1985 ;$ c1976. p. 81.

[9] Alexander C. A city is not a tree. Design. London: Council of Industrial Design; 1966. p. 206.

[10] Hilberseimer L. Der Wille zur Architektur. Das Kunstblatt. 1923. p. 133-140.

[11] Riegl A. Spätrömische Kunstindustrie: nach den Funden in Österreich-Ungarn. Wien: Verlag der kaiserlichen und königlichen Hof- und Staatsdruckerei; 1901.

[12] Smith B. Structure and Gestalt: philosophy and literature in Austria-Hungary and her successor states. Amsterdam: John Benjamins Publishing; 1981. p. 55.

[13] Translated from German: 'Verknüpfungsganzes.' In: Husserl E, editor. Logische Untersuchungen: Zweiter Teil Untersuchungen zur Phänomenologie und Theorie der Erkenntnis. Halle an der Saale: Max Niemeyer; 1901. p. $223-225$.

[14] Ridder L. Mereologie: Ein Beitrag zur Ontologie und Erkenntnistheorie. (Bd. 83). Frankfurt am Main: V. Klostermann; 2002.

[15] Rescher N, Oppenheim P. Logical analysis of gestalt concepts. Br J Philos Sci. [Internet]. 1955; 6: p. 89-106.

[16] Available from: http://en.wiktionary.org/wiki/digital

[17] Carpo M. Breaking the curve: big data and design. Artforum. 2014 Feb.

[18] Bratton BH. The stack: on software and sovereignty. (Software studies). Cambridge, (MA): MIT press; 2016. p. 368.

[19] Köhler D. The Mereological city: a reading of the works of Ludwig Hilberseimer. Bielefeld, New York (NY): transcript; 2016. p. 47-58.

[20] Hilberseimer L. Elements of city planning. Armour Engineer and Alumnus. 12/1940:4-14. p. 12.

[21] Eastman CM. BIM handbook: a guide to building information modeling for owners, managers, designers, engineers and contractors. 2nd ed. Hoboken (NJ): Wiley; 2011. p. 32.

[22] American Institute of Architects. AIA Document E202-2008: building information modeling protocol exhibit. 2008.

[23] Mackay R, Avanessian A, editors. \#Accelerate\#. [Falmouth, UK]. Berlin: Urbanomic Media Ltd.; in association with Merve; 2014. p. 23. 